\title{
The effect of Training and Placement of Employees on Employee Performance in PT. Bank Danamon tbk, Kuningan-Jakarta
}

\author{
Dede Andi \\ Univesitas Pamulang \\ E-mail: dosen02463@unpam.ac.id
}

(Received: June-2019; revised: August -2019; published: December -2019)

\begin{abstract}
This research aims to study the training and placement of employees at PT. Bank Danamon Tbk, Kuningan-Jakarta. The method used is explanatory research with a sample of 55 respondents. The analysis technique uses statistical analysis with regression testing, evaluation, determination and hypothesis testing. The results of this study significantly improved employee performance by $48.3 \%$, the hypothesis test obtained significance of $0,000<0.05$. Significant job placement on employee performance by $34.4 \%$, hypothesis testing obtained significance of $0,000<0.05$. Training and work placement is significant on employee performance by $56.2 \%$, hypothesis testing obtained significance $0,000<0.05$.
\end{abstract}

Keywords: Training, Job placement, Employee Performance.

\section{INTRODUCTION}

The development of the industrial world is currently experiencing very rapid progress where resources become the basis of knowledge and creativity for industry players both service and manufacturing industries in the ability of an industry to face competition (Akib, 2011; Grant, 1996; Prasodjo, 2019). The banking service industry in Indonesia is one of the priority sectors, the growth of the banking services industry. One of the measurement tools used to measure the quality and performance of banks is the total assets owned by the bank where the greater the assets they have, the greater the quality and performance of the bank (Dharma \& Akib, 2005; Hariyono et al., 2019; Niswaty et al., 2015; Saggaf et al., 2018; Souisa et al., 2019).

One of the factors that influence the success rate of an organization is the performance of its employees. Employee performance is an action taken by employees in carrying out work provided by the company (Handoko, 2010). Improved employee performance will bring progress for the company to be able to survive in an unstable business environment competition. Therefore efforts to improve employee performance are the most serious management challenges because success in achieving goals and survival of the company depends on the quality of the performance of the human resources that are in it. High employee performance is expected by the company, the more employees who have high performance, the overall productivity of the company will increase so that the company will be able to survive in global competition (Bare et al., 2019; Mattayang et al., 2019; Mukmin et al., 2020; Syam et al., 2018, 2018). 
PT. Bank Danamon is a banking service industry in Indonesia where Bank Danamon's business entity is a Limited Liability Company (PT). The bank has been operating for a long time to serve customers through the services and products they offer.

Performance is one of the things that companies need to pay attention to. The success of company goals is greatly influenced by the performance of its employees. In order for a company to achieve its goals, the company must always improve the performance of its employees. Optimal employee performance is a reflection of quality resources. According to (Prabu Mangkunegara, 2011), In carrying out this training there are several dimensions and indicators including quality, quantity, implementation of tasks and responsibilities. The company has a goal to increase the value of a superior company in their field, so that with this goal each employee is required to be able to provide maximum service to its customers by working according to their duties properly, so as to become a company that excels in their fields. But the reality in the field of efforts there are problems that can hinder the work process of employees such as: the existence of work assignments that must be completed but not well understood, limited ability, the existence of a new system that must be given training, the current work is not according to their educational background, the quality and quantity of work they feel is lacking. For example, one employee in quantity can complete work on target. However, when discussing quality problems, the results of work performed are not good. Initial allegations regarding the cause of employee quality is not good comes from the company. For example, in the recruitment process, as well as training.

Then responsibility is also one of the causes of poor performance (Chams \& GarcíaBlandón, 2019; Lobanova \& Ozolina-Ozola, 2014; Sunarsi, 2019; Zaid et al., 2018; Zehir et al., 2016). According to the employee's recognition, many employees were dissatisfied because of occupying a position they were less interested in. As a result, employees feel less responsible for the work they occupy, which affects performance. From observations indicated that the variables that influence the low performance of employees at the Company are the training and placement variables. Training variables and placement variables. Therefore, companies must improve the quality of training and make appropriate employee placements so that employee performance is optimal. Based on the background that has been described, the authors are interested in conducting research with the title "The Effect of Training and Job Placement on Employee Performance at PT. Bank Danamon Tbk, Kuningan-Jakarta ".

\section{METHOD}

The type of research used is associative (Creswell \& Creswell, 2017). The population in this study amounted to 55 respondents PT. Bank Danamon Tbk, Kuningan-Jakarta. The sampling technique in this study is saturated sampling, where all members of the population are sampled. Thus the sample in this study amounted to 55 respondents. In analyzing the data used the instrument test, classical assumption test, regression, coefficient of determination and hypothesis testing (Sugiyono, 2010). 


\section{RESULT AND DISCUSSION}

\section{Result}

\section{Descriptive Analysis}

In this test used to determine the minimum and maximum scores, mean scores and standard deviations of each variable. The results are as follows:

Table 1.

Results of Descriptive Statistics Analysis

Descriptive Statistics

\begin{tabular}{l|r|r|r|r|r}
\hline & $\mathrm{N}$ & Minimum & Maximum & The mean & Std. Deviation \\
\hline Training (X1) & 55 & 31 & 48 & 38.45 & 4,396 \\
\hline Work Placement (X2) & 55 & 32 & 48 & 38.36 & 3,768 \\
\hline Employee Performance (Y) & 55 & 33 & 46 & 39.27 & 3,582 \\
\hline Valid N ( listwise ) & 55 & & & & \\
\hline
\end{tabular}

The training obtained a minimum variance of 31 and a maximum variance of 48 with a mean score of 3.84 with a standard deviation of 4.396 . Work placements obtained a minimum variance of 32 and a maximum variance of 48 with a mean score of 3.83 with a standard deviation of 3.768. Employee performance obtained a minimum variance of 33 and a maximum variance of 46 with a mean score of 3.92 with a standard deviation of 3.582 .

\section{Verification Analysis.}

This analysis is intended to determine the effect of independent variables on the dependent variable. The test results are as follows:

\section{a. Multiple Linear Regression Analysis}

This regression test is intended to determine changes in the dependent variable if the independent variable changes. The test results are as follows:

Table 2.

Results of Multiple Liner Regression Testing

\section{Coefficients $^{\text {a }}$}

\begin{tabular}{|c|c|c|c|c|c|}
\hline \multirow[b]{2}{*}{ Model } & \multicolumn{2}{|c|}{$\begin{array}{l}\text { Unstandardized } \\
\text { Coefficients }\end{array}$} & \multirow{2}{*}{$\begin{array}{c}\text { Standardized } \\
\text { Coefficients } \\
\text { Beta } \\
\end{array}$} & \multirow[b]{2}{*}{$\mathrm{t}$} & \multirow[b]{2}{*}{ Sig. } \\
\hline & B & Std. Error & & & \\
\hline $1 \quad$ (Constant) & 10,715 & 3,647 & & 2,938 & .005 \\
\hline Training (X1) & 437 & .86 & .536 & 5,085 & .000 \\
\hline Work Placement (X2) & .306 & .100 & 322 & 3,054 & .004 \\
\hline
\end{tabular}

a. Dependent Variable: Employee Performance (Y) 
Based on the test results in the above table, the regression equation $\mathrm{Y}=10.715+0.438 \mathrm{X} 1$ $+0.306 \mathrm{X} 2$ is obtained. From the equation explained as follows:

1) A constant of 10.715 means that if there is no training and work placement, then there is an employee performance value of 10.715 points.

2) The training regression coefficient of 0.438 , this number is positive, meaning that every time there is an increase in training of 0.438 , the employee's performance will also increase by 0.438 points.

3) Work placement regression coefficient of 0.306 , this number is positive, meaning that every time there is an increase in work placement of 0.306 , employee performance will also increase by 0.306 points.

\section{b. Correlation Coefficient Analysis}

Correlation coefficient analysis is intended to determine the degree of relationship strength of the independent variables on the dependent variable either partially or simultaneously. The test results are as follows:

Table 3.

Testing Results for Training Correlation Coefficient on Employee Performance .

\section{Correlations $^{b}$}

\begin{tabular}{llr|r}
\hline & & \multicolumn{2}{c}{$\begin{array}{c}\text { Employee } \\
\text { Praining (X1) }\end{array}$} \\
\hline Training (X1) & Pearsonance (Y) \\
\cline { 2 - 4 } & Sig. (2-tailed) & 1 & $.955^{* *}$ \\
\hline Employee Performance (Y) & Pearson Correlation & $.955^{* *}$ & .000 \\
\cline { 2 - 4 } & Sig. (2-tailed) & .000 & 1 \\
\hline
\end{tabular}

**. Correlation is significant at the 0.01 level (2-tailed).

b. Listwise $\mathrm{N}=55$

Based on the test results obtained a correlation value of 0.695 means that training has a strong relationship with employee performance .

Table 4.

Correlation Coefficient Testing Results Work Placement Against Employee Performance

\section{Correlations $^{\text {b }}$}

\begin{tabular}{|c|c|c|c|}
\hline & & Work Placement (X2) & Employee Performance (Y) \\
\hline \multirow{2}{*}{$\begin{array}{l}\text { Work Placement } \\
\text { (X2) }\end{array}$} & Pearson Correlation & 1 & $.877^{* *}$ \\
\hline & Sig. (2-tailed) & & .000 \\
\hline Employee & Pearson Correlation & $.877^{* *}$ & 1 \\
\hline Performance (Y) & Sig. (2-tailed) & .000 & \\
\hline
\end{tabular}

**. Correlation is significant at the 0.01 level (2-tailed).

b. Listwise $\mathrm{N}=55$ 
Based on the test results obtained a correlation value of 0.587 means that work placement has a moderate relationship to employee performance .

Table 5.

Results of Correlation Coefficient Testing Training and Job placement simultaneously on Employee Performance .

\begin{tabular}{lr|rr|r} 
& \multicolumn{4}{c}{ Summary Model } \\
Model & R & R Square & Adjusted R Square & Std. Error of the Estimate \\
\hline 1 & $.750^{\mathrm{a}}$ & .562 & .545 & 2,416 \\
\hline
\end{tabular}

a. Predictors: (Constant), Work Placement (X2), Training (X1)

Based on the test results obtained a correlation value of 0.750 means that training and work placement simultaneously has a strong relationship to employee performance .

\section{c. Analysis of the Coefficient of Determination}

Analysis of the coefficient of determination is intended to determine the percentage of influence of the independent variable on the dependent variable either partially or simultaneously. The test results are as follows:

Table 6.

Results of the Training Determination Coefficient Tests on Employee Performance .

Summary Model

\begin{tabular}{lr|r|r|r}
\hline Model & R & R Square & Adjusted R Square & Std. Error of the Estimate \\
\hline 1 & $.695^{\text {a }}$ & .483 & .474 & 2,599 \\
\hline
\end{tabular}

a. Predictors: (Constant), Training (X1)

Based on the test results obtained a determination value of 0.483 means that training has an influence contribution of $48.3 \%$ on employee performance .

Table 7.

Test Results for the coefficient of determination of work placement on employee performance .

Summary Model

\begin{tabular}{lr|rr|r}
\hline Model & $\mathrm{R}$ & R Square & Adjusted R Square & Std. Error of the Estimate \\
\hline 1 & $.587^{\mathrm{a}}$ & .344 & .322 & 2,928 \\
\hline
\end{tabular}

a. Predictors: (Constant), Work Placement (X2)

Based on the test results obtained a determination value of 0.344 means that work placement has an influence contribution of $34.4 \%$ on employee performance . 
212 Jurnal Administrare: Jurnal Pemikiran Ilmiah dan Pendidikan Administrasi Perkantoran Volume 6 No. 2 July - December 2019. Pages 207-216

Table 8.

Testing Results Coefficient Determination of Training and Work Placement Against Employee Performance .

\section{Summary Model}

\begin{tabular}{lr|r|r|r}
\hline Model & R & R Square & Adjusted R Square & Std. Error of the Estimate \\
\hline 1 & $.750^{\mathrm{a}}$ & .562 & .545 & 2,416 \\
\hline
\end{tabular}

a. Predictors: (Constant), Work Placement (X2), Training (X1)

Based on the test results obtained a determination value of 0.562 means that training and work placement simultaneously has an influence contribution of $56.2 \%$ on employee performance, while the remaining $43.8 \%$ is influenced by other factors.

\section{d. Hypothesis testing}

\section{1) Partial hypothesis test (t test)}

Hypothesis testing with $\mathrm{t}$ test is used to find out which partial hypotheses are accepted. First Hypothesis: There is a significant influence between training on employee performance .

Table 9.

Results of Training Hypothesis Tests on Employee Performance .

Coefficients $^{\text {a }}$

\begin{tabular}{|c|c|c|c|c|c|c|}
\hline \multirow{2}{*}{\multicolumn{2}{|c|}{ Model }} & \multicolumn{2}{|c|}{ Unstandardized Coefficients } & \multirow{2}{*}{$\frac{\text { Standardized Coefficients }}{\text { Beta }}$} & \multirow[b]{2}{*}{ [ } & \multirow[b]{2}{*}{ Sig. } \\
\hline & & B & Std. Error & & & \\
\hline \multirow[t]{2}{*}{1} & (Constant) & 17,490 & 3,114 & & 5,617 & .000 \\
\hline & Training $(\mathrm{X} 1)$ & .566 & .080 & 695 & 7,041 & .000 \\
\hline
\end{tabular}

a. Dependent Variable: Employee Performance (Y)

Based on the test results in the above table, the value of $t$ count $>t$ table or $(7.401>2.006)$ is obtained, thus the first hypothesis proposed that there is a significant influence between training on employee performance is accepted.

Table 10.

Hypothesis Test Results for Work Placement Against Employee Performance .

Coefficients ${ }^{\text {a }}$

\begin{tabular}{|c|c|c|c|c|c|c|}
\hline \multirow{2}{*}{\multicolumn{2}{|c|}{ Model }} & \multicolumn{2}{|c|}{$\begin{array}{l}\text { Unstandardized } \\
\text { Coefficients }\end{array}$} & \multirow{2}{*}{$\begin{array}{l}\text { Standardized } \\
\text { Coefficients } \\
\text { Beta } \\
\end{array}$} & \multirow[b]{2}{*}{$\mathrm{t}$} & \multirow[b]{2}{*}{ Sig. } \\
\hline & & B & Std. Error & & & \\
\hline & (Constant) & 17,880 & 4,076 & & 4,386 & .000 \\
\hline & $\begin{array}{l}\text { Work Placement } \\
(\mathrm{X} 2)\end{array}$ & .558 & .106 & 587 & 5,273 & .000 \\
\hline
\end{tabular}

a. Dependent Variable: Employee Performance (Y) 
Based on the test results in the table above, the value of $t$ count $>t$ table or $(5.273>2.006)$ is obtained, thus the second hypothesis is proposed that there is a significant influence between work placement on employee performance received.

\section{2) Simultaneous Hypothesis Test (Test F)}

Hypothesis testing with the $\mathrm{F}$ test is used to find out which simultaneous hypotheses are accepted. The third hypothesis There is a significant influence between training and work placement on employee performance .

Table 11.

Training Hypothesis Test Results and Job Placement Against Employee Performance .

\begin{tabular}{|c|c|c|c|c|c|}
\hline \multicolumn{6}{|c|}{ ANOVA $^{a}$} \\
\hline Model & Sum of Squares & $\mathrm{df}$ & Mean Square & $\mathrm{F}$ & Sig. \\
\hline Regression & 389,337 & 2 & 194,668 & 33,345 & $.000^{\mathrm{b}}$ \\
\hline Residual & 303,572 & 52 & 5838 & & \\
\hline Total & 692.909 & 54 & & & \\
\hline
\end{tabular}

a. Dependent Variable: Employee Performance (Y)

b. Predictors: (Constant), Work Placement (X2), Training (X1)

Based on the test results in the above table, the calculated $F$ value> F table or (18.770> 2.780 ), thus the third hypothesis proposed that there is a significant influence between training and work placement on employee performance is accepted.

\section{Discussion}

\section{The Effect of Training on Employee Performance}

Training has a significant effect on employee performance with a correlation of 0.695 or has a strong relationship with a contribution of $48.3 \%$. Hypothesis testing obtained $t$ value $>t$ table or $(7.401>2.006)$. Thus the first hypothesis proposed that there is a significant effect between training on employee performance is accepted.

\section{Effect of Job Placement on Employee Performance}

Job placement has a significant effect on employee performance with a correlation of 0.587 or has a moderate relationship with a contribution of $34.4 \%$. Hypothesis testing obtained $t$ value $>t$ table or $(5.273>2.006)$. Thus the second hypothesis proposed that there is a significant effect between work placement on employee performance is accepted.

\section{The Effect of Training and Work Placement on Employee Performance}

Training and work placement have a significant effect on employee performance by obtaining a regression equation $\mathrm{Y}=10.715+0.438 \mathrm{X} 1+0.306 \mathrm{X} 2$, a correlation value of 0.750 
214 Jurnal Administrare: Jurnal Pemikiran Ilmiah dan Pendidikan Administrasi Perkantoran
Volume 6 No. 2 July - December 2019. Pages 207-216

or having a strong relationship with a contributing effect of $56.2 \%$ while the remaining $43.8 \%$ is influenced by other factors. Hypothesis testing obtained $F$ value $>F$ table or $(18.770>2.780)$. Thus the third hypothesis proposed that there is a significant effect between training and work placement on employee performance is accepted.

\section{CONCLUSION}

Training has a significant effect on employee performance with an influence contribution of $48.3 \%$. Hypothesis testing obtained $t$ count $>t$ table or $(7.401>2.006)$. Job placement has a significant effect on employee performance with an influence contribution of $34.4 \%$. Hypothesis testing obtained $t$ value> $t$ table or (5.273> 2.006). Training and work placement significantly influence employee performance with an influence contribution of $56.2 \%$ while the remaining $43.8 \%$ is influenced by other factors. Hypothesis testing obtained the value of $\mathrm{F}$ count> F table or (18.770> 2.780).

\section{REFERENCES}

Akib, H. (2011). Mencermati heuristik transformasi organisasi: Mereaktualisasi perilaku kreatif manusia melalui pendekatan knowledge management. Jurnal Manajemen Usahawan Indonesia, 40(3), 225-244.

Bare, R. R., Akib, H., Anshari, A., Haris, H., \& Salam, R. (2019). Snapshot of the Competitiveness of Senior High Schools (SMA) in Toraja Utara Regency, Indonesia. Indonesia (August 28, 2019).

Chams, N., \& García-Blandón, J. (2019). On the importance of sustainable human resource management for the adoption of sustainable development goals. Resources, Conservation and Recycling, 141, 109-122. https://doi.org/https://doi.org/10.1016/j.resconrec.2018.10.006

Creswell, J. W., \& Creswell, J. D. (2017). Research design: Qualitative, quantitative, and mixed methods approaches. Sage publications.

Dharma, S., \& Akib, H. (2005). The Influence of Job Satisfaction on Work Performance: a Theoretical Approach. Manajemen USAHAWAN Indonesia,(2), 30-33.

Grant, R. M. (1996). Knowledge, strategy and the theory oi the firm. Strategic Management Journal, 17, 109-122.

Handoko, T. H. (2010). Manajemen Pemasaran. Yogyakarta: BPFE.

Hariyono, U. S., Sopyan, Y., Akib, H., Haris, H., Paraga, S., \& Astuti, A. (2019). The Effectiveness of the Performance of Civil Servants in the Integrated Service Office in Gowa Regency. 1st International Conference on Advanced Multidisciplinary Research (ICAMR 2018).

Lobanova, L., \& Ozolina-Ozola, I. (2014). Comparative Evaluation of the Practical Areas of Human Resource Management in Lithuania and Latvia. Procedia - Social and Behavioral 
Sciences, 110, 607-616. https://doi.org/https://doi.org/10.1016/j.sbspro.2013.12.905

Mattayang, B., Syam, H., Akib, H., \& Syukur, M. (2019). Snapshot Level of Principal Entrepreneurs Competency. International Conference on Social Science 2019 (ICSS 2019).

Mukmin, A., Akib, H., Samad, S., Cahaya, A., \& Kamaluddin, L. A. (2020). Mastery of Principal Entrepreneurship Competencies in Senior High Schools in Sinjai Regency, Indonesia. Indonesia (January 3, 2020).

Niswaty, R., Manno, J., \& Akib, H. (2015). An analysis of the public service performance based on human development index in makassar city, Indonesia. International Journal of Applied Business and Economic Research (IJABER), 13(6), 4421-4429.

Prabu Mangkunegara, A. (2011). Manajemen Sumber Daya Manusia Perusahaan. Bandung: PT. Remaja Rosdakarya.

Prasodjo, T. (2019). Knowledge Management: Sustainable Human Resource Development in Public Sector Organizations. Jurnal Ad'ministrare, 6(2), 159-166.

Saggaf, M. S., Aras, M., Akib, H., Salam, R., Baharuddin, A., \& Kasmita, M. (2018). The Quality Analysis of Academic Services Based on Importance Performance Analysis (IPA).

Souisa, W., Musa, C. I., Akib, H., \& Bado, B. (2019). Determinats of the Performance of Cooperative Manager in Ambon City, Indonesia. Journal of Entrepreneurship Education.

Sugiyono. (2010). Metode Penelitian Bisnis. Pendekatan Kuantitatif, kualitatif dan R \& D. Bandung: Alfabeta.

Sunarsi, D. (2019). The Analysis of The Work Environmental and Organizational Cultural Impact on The Performance and Implication of The Work Satisfaction. Jurnal Ilmiah Ilmu Administrasi Publik, 9(2), 113-122.

Syam, H., Akib, H., Patonangi, A. A., \& Guntur, M. (2018). Principal Entrepreneurship Competence Based on Creativity and Innovation in the Context of Learning Organizations in Indonesia. Journal of Entrepreneurship Education, 21(3), 1-13.

Zaid, A. A., Jaaron, A. A. M., \& Talib Bon, A. (2018). The impact of green human resource management and green supply chain management practices on sustainable performance: An empirical study. Journal of Cleaner Production, 204, 965-979. https://doi.org/https://doi.org/10.1016/j.jclepro.2018.09.062

Zehir, C., Gurol, Y., Karaboga, T., \& Kole, M. (2016). Strategic Human Resource Management and Firm Performance: The Mediating Role of Entrepreneurial Orientation. Procedia Social and Behavioral Sciences, 235, 372-381. https://doi.org/https://doi.org/10.1016/j.sbspro.2016.11.045 
216 |Jurnal Administrare: Jurnal Pemikiran Ilmiah dan Pendidikan Administrasi Perkantoran Volume 6 No. 2 July - December 2019. Pages 207-216 